\title{
REINFORCEMENT KOMPETENSI GURU DALAM MENINGKATKAN KUALITAS PEMBELAJARAN
}

\author{
Mohammad Zaini \\ Institut Agama Islam Negeri (IAIN) Jember \\ mohzainimm@gmail.com
}

\begin{abstract}
This article aims to describe the reinforcement of teacher competence is a continuous thing to do in sustainability because it is about mastery of the learning process in the school. Learning is helping students gain a variety of experiences, so that students' behavior increases, both quantity and quality. The experience includes knowledge, skills and values or norms that serve as controlling attitudes and behaviors. Learning is done by setting up a variety of interactions that exist in and around learning moments that include effective learning elements that influence student success. Good learning according to the Gestalt tradition, which is an attempt to give the subject matter in such a way that students more easily organize it (organize it) into a meaningful pattern.
\end{abstract}

Keywords: Reinforcement, Teacher Competency, Learning

\begin{abstract}
Abstrak
Tulisan ini bertujuan untuk mendeskripsikan penguatan (reinforcement) kompetensi guru merupakan hal terus dilakukan secara keberlanjutan karena terkait tentang penguasaan terhadap proses pembelajaran di sekolah. Pembelajaran adalah membantu siswa agar memperoleh berbagai pengalaman, sehingga tingkah laku siswa bertambah, baik kuantitas maupun kualitas. Pengalaman tersebut meliputi pengetahuan, ketrampilan dan nilai atau norma yang berfungsi sebagai pengendali sikap dan perilaku. Pembelajaran dilakukan dengan pengaturan bermacammacam interaksi yang ada di dalam dan di sekitar momen belajar yang mencakup unsur-unsur belajar efektif yang mempengaruhi kesuksesan siswa. Pembelajaran yang baik menurut aliran Gestalt, yaitu usaha untuk memberi materi pelajaran sedemikian rupa sehingga siswa lebih mudah mengorganisasikannya (mengaturnya) menjadi suatu pola bermakna.
\end{abstract}

Kata Kunci: Reinforcement, Kompetensi Guru, Pembelajaran

\section{PENDAHULUAN}

Penguatan komunikasi guru dapat dijadikan tolok ukur untuk menunjang keberhasilan dalam kegiatan belajar sebagaimana yang dijelaskan dalam UU. RI. Tahun 2003 tentang Sistem Pendidikan Nasional Bab XI tentang Pendidikan, sebagai berikut:

"Pendidik merupakan tenaga profesional yang bertugas merencanakan dan melaksanakan proses pembelajaran, menilai hasil pembelajaran, melakukan pembimbingan dan pelatihan, serta melakukan penelitian dan pengabdian kepada masyarakat terutama bagi pendidik pada perPendidik dan tenaga kependidikannya tinggi”.

\footnotetext{
${ }^{1}$ Undang-Undang No. 20 Tahun 2003 tentang Sistem Pendidikan Nasional, Bab I Pasal I ayat (2)
}

Falasifa, Vol. 11 Nomor 2 September 2020|92 
Di dalam Undang-Undang No. 20 Tahun 2003 tentang Sistem Pendidikan Nasional, Bab I Pasal I ayat (2) disebutkan bahwa "Pendidikan Nasional adalah pendidikan Pancasila dan Undang-Undang Dasar Negara Republik Indonesia Tahun 1945, yang berakar pada nilai-nilai agama, kebudayaan nasional Indonesia dan tanggap terhadap tuntutan perubahan zaman”. Pernyataan ini mengandung arti bahwa semua aspek yang terdapat dalam Sistem Pendidikan Nasional akan mencerminkanm aktifitas yang dijiwai oleh Pancasila dan Undang-undang Dasar 1945 dan berakar pada nilai-nilai agama serta kebudayaan nasional Indonesia.Tujuan Pendidikan Nasional yang dimaksud di sini adalah tujuan akhir yang akan dicapai oleh semua lembaga pendidikan, baik formal, non formal, informal yang berada dalam masyarakat dan negara Indonesia.Pendidikan merupakan suatu kegiatan yang universal dalam kehidupan manusia, sehingga di manapun terdapat masyarakat di situ pula terdapat pendidikan.

Pendidikan itu sendiri merupakan tanggung jawab bersama antara masyarakat, pemerintah dan keluarga. Guru mempunyai peran yang cukup besar terhadap pelaksanaan pendidikan bagi anak didiknya, sebab dalam kehidupan sehari-hari anak selalu di didik oleh guru di sekolah. Dengan demikian orang tua diharapkan berperan aktif dalam pendidikan anak didiknya dengan mendidik dan memberi dorongan dalam belajar dirumah agar mereka memperoleh prestasi yang optimal dan berupaya untuk memenuhi kebutuhan serta bimbingan terhadap anak-anaknya sehingga anak tersebut memiliki sifat-sifat dasar sebagai warga negara yang baik. Hal ini sesuai dengan pendapat W. Sardiman yang menyatakan bahwa:

"Pendidikan berarti usaha yang dijalankan oleh seseorang atau sekelompok orang lain agar menjadi dewasa atau mencapai tingkat hidup dan penghidupan yang lebih tinggi dalam arti mental"'2

Dengan adanya komunikasi guru maka akan timbul suatu penggalian potensi siswa dengan semangat dan keaktifan anak didik dalam belajar. Apabila guru dalam proses pembelajarannya tidak berdasarkan Profesionalisme yang dimilikinya maka akan berakibat tidak adanya kejelasan dalam penguasaan dan penggalian potensi kepada anaknya, sehingga anak akan mengalami banyak kesulitan dalam belajar. Bagi anak yang memiliki potensi serta didukung dengan komunikasi gurunya maka akan mempunyai banyak energi untuk melakukan kegiatan-kegiatan belajar. Tetapi bagi seorang siswa yang telah memiliki intelegensi kuat, tetapi

\footnotetext{
${ }^{2}$ Sardiman, A,M. Interaksi dan Motivasi Belajar Mengajar. (Jakarta: Rajawali. 1990)
}

Falasifa, Vol. 11 Nomor 2 September 2020 | 93 


\section{Mohammad Zaini}

kurang didukung oleh Komunikasi guru boleh jadi gagal. Jadi jelaslah bahwa hasil belajar itu akan optimal apabila adanya dukungan seorang guru yang bisa mengkomunikasikan suatu mata pelajaran yang dimilki oleh guru itu.

Hambatan dan rintangan, baik yang berasal dari luar diri anak didik maupun dari dalam diri anak didik dalam proses pembelajaran itu juga dapat terindikasi adanya komunikasi guru yang dimiliki oleh seorang pendidik. oleh sebab itu nilai komunikasi sangat diperlukan karena dapat menunjang keberhasilan anak dalam mencapai prestasi di sekolah maupun di Madrasah. Dalam rangka memperoleh prestasi belajar yang baik, maka diperlukan adanya kebiasaankebiasaan belajar yang baik. Misalnya anak terbiasa belajar dengan teratur, tekun, rajin, dan juga perlu ditanamkan kedisiplinan. Semua ini dapat diperoleh dari dorongan-dorongan dan pengawasan-pengawasan guru bekerja sama dengan orang tua, sehingga dapat menemukan keberhasilan dalam belajar dan mencapai prestasi yang tinggi. Dan prestasi belajar dapat diperoleh melalui proses belajar yang dilakukan dengan penuh kesadaran dan berlangsung dalam waktu tertentu, misalnya dapat berwujud perubahan tingkah laku maupun intelegensinya, jadi tidak benar bila ada anggapan bahwa belajar hanya dapat dilakukan di sekolah saja, melainkan dapat dilakukan pada setiap waktu.

\section{PEMBAHASAN}

\section{Guru dalam lingkup pendidikan}

Guru adalah faktor pendidikan yang sangat penting dan mempunyai peran yang paling strategis, sebab gurulah sebetulnya pemain yang paling menentukan dalam proses belajar mengajar. Guru sebagai pendidik profesional mempunyai citra yang baik di masyarakat apabila dapat menunjukkan kepada masyarakat bahwa ia layak menjadi panutan atau teladan masyarakat sekelilingnya. ${ }^{3}$

Dalam Undang-Undang no 14 tahun 2005 tentang guru dan dosen dinyatakan bahwa "Guru adalah pendidik profesional dengan tugas utama mendidik, mengajar, membimbing, mengarahkan, melatih, menilai, dan mengevaluasi peserta didik pada pendidikan anak usia dini jalur pendidikan formal, pendidikan dasar, dan pendidikan menengah" (UU No 14 tahun 2005 tentang Guru dan Dosen bab I pasal I).

Oleh sebab itu masyarakat akan melihat bagaimana sikap dan perbuatan guru seharihari apakah memang ada yang patut di teladani atau tidak. Guru juga merupakan faktor kunci

\footnotetext{
${ }^{3}$ Soetjipto, 2000, Profesi Keguruan, (Jakarta, Reneka Cipta), 42

94 | Falasifa, Vol. 11 Nomor 2 September 2020
} 
Reinforcement Kompetensi Guru Dalam Meningkatkan

sukses dari upaya untuk meningkatkan kualitas pendidikan dasar dan menengah. Guru memegang peranan sentral dan strategis dalam rangka pembangunan SDM, karena pembangunan pendidikan nasional tidak terpisahkan dari perubahan. Perubahan yang berlangsung di dalam kelas hal itu di sebabkan karena adanya interaksi antara guru dan siswa.

Guru adalah profesi dan bukan sekedar pekerjaan atau karir. Oleh sebab itu seorang guru akan memiliki jiwa profesionalisme. ${ }^{4}$ Profesional disini dalam bidangnya, memiliki moral yang tinggi, panutan etika, serta memiliki identitas kebangsaan yang kokoh. Guru menempati kedudukan yang terhormat di masyarakat. kewibawaan yang menyebabkan guru dihormati, sehingga masyarakat tidak meragukan figur guru. Guru adalah jabatan profesional yang memerlukan berbagai keahlian khusus.

\section{Syarat-syarat bagi seorang guru}

Sebagaimana dijelaskan dalam Undang-Undang no 14 tahun 2005 tentang Guru dan Dosen bab III pasal 7 tentang profesi guru dan profesi dosen merupakan bidang pekerjaan khusus yang dilaksanakan berdasarkan prinsip sebagai berikut:

a. Memiliki bakat, minat, panggilan jiwa, dan idealisme;

b. Memiliki komitmen untuk meningkatkan mutu pendidikan, keimanan,ketakwaan, dan akhlak mulia;

c. Memiliki kualifikasi akademik dan latar belakang pendidikan sesuai dengan bidang tugas;

d. Memiliki kompetensi yang diperlukan sesuai dengan bidang tugas;

e. Memiliki tanggung jawab atas pelaksanaan tugas keprofesionalan;

f. Memperoleh penghasilan yang ditentukan sesuai dengan prestasi kerja;

g. memiliki kesempatan untuk mengembangkan keprofesionalan secara berkelanjutan dengan belajar sepanjang hayat;

h. Memiliki jaminan perlindungan hukum dalam melaksanakan tugas keprofesionalan; dan

i. Memiliki organisasi profesi yang mempunyai kewenangan mengatur hal-hal yang berkaitan dengan tugas keprofesionalan guru. ${ }^{5}$

Menurut Hamalik bahwa guru yang profesional maka harus memepunyai kriteria

\footnotetext{
${ }^{4}$ You Tung, Khoe, Simpone Sendih Pendidikan Nasional, Refleksi Dunia Pendidikan Nasional Kumpulan Artikel Tentang Ulasan Kritis Tentang Kepedihan, Kegetiran Dan Keprihatinan Atas Kritis Pendidikan Kita, (Jakarta, Abadi Tandur), 28

${ }^{5}$ Undang-Undang no 14 tahun 2005 tentang Guru dan Dosen Falasifa, Vol. 11 Nomor 2 September 2020 | 95
} 


\section{Mohammad Zaini}

profesional antara lain:

a. fisik

1. Sehat jasmani dan rohani

2. Tidak mempunyai cacat tubuh yang bisa menimbulkan ejekan/ cemoohan atau rasa kasihan dari anak didik.

b. Mental/ Kepribadian

1. Berkepribadian/berjiwa pancasila

2. Mampu menghayati GBHN

3. Mencintai bangsa dan sesama manusia dan rasa kasih sayang kepada anak didik.

4. Berbudi pekerti yang luhur.

5. Berjiwa kreatif, dapat memanfaatkan rasa pendidikan yang ada secara maksimal.

6. Mampu menyuburkan sikap demokrasi dan penuh tenggang rasa.

7. Mampu mengembangkan kreativitas dan tanggung jawab yang besar akan tugasnya.

8. Mampu mengembangkan kecerdasan yang tinggi.

9. Bersikap terbuka, peka, dan inovatif.

10. Menunjukkan rasa cinta kepada profesinya.

11. Ketaatannya akan disiplin.

c. Keilmiahan/Pengetahuan

1. Memahami ilmu yang dapat melandasi pembentukan pribadi

2. Memahami ilmu pendidikan dan keguruan dan mampu menerapkannya dalam tugasnya sebagai pendidik.

3. Memahami, menguasai, serta mencintai ilmu pengetahuan yang akan diajarkan.

4. Memiliki pengetahuan yang cukup tentang bidang-bidang yang lain.

5. Senang membaca buku-buku ilmiah.

6. Mampu memecahkan persoalan secara sistematis, terutama yang berhubungan dengan bidang studi.

7. Memahami prinsip- prinsip kegiatan belajar mengajar.

d. Keterampilan (skill)

1. Mampu berperan sebagai organisator proses belajar mengajar.

2. Mampu menyusun bahan pelajaran atas dasar pendekatan struktural, interdisipliner, fungsional, behavior, dan teknologi.

96 | Falasifa, Vol. 11 Nomor 2 September 2020 
3. Mampu menyusun garis besar program pengajaran (GBPP).

4. Mampu melaksanakan dan memecahkan teknik- teknik mengajar yang baik dalam memcapai tujuan pendidikan.

5. Mampu merencanakan dan melaksanakan evaluasi pendidikan.

6. Memahami dan mampu melaksanakan kegiatan dan pendidikan luar sekolah. ${ }^{6}$

Untuk melaksanakan tugas mengajar dengan baik saeorang guru harus memiliki kemampuan profesional yang meliputi:

1. Menguasai Landasan Pendidikan

a. Mengenal tujuan pendidikan untuk mencapai tujuan pendidikan nasional

1. Mengkaji tujuan pendidikan nasional

2. Mengkaji tujuan pendidikan dasar dan menengah

3. Meneliti kegiatan antara tujuan pendidikan dasar dan menengah dengan tujuan pendidikan nasional.

4. Mengkaji kegiatan- kegiatan pengajaran yang menunjang pencapaian tujuan pendidikan nasional

b. Mengenal fungsi sekolah dalam masyarakat.

1. Mengkaji peranan sekolah sebagai pusat pendidikan dan kebudayaan.

2. Mengkaji peristiwa- peristiwa yang mencerminkan sekolah sebagai pusat pendidikan dan kebudayaan.

3. Mengelola kegiatan sekolah yang mencerminkan sekolan sebagai pusat pendidikan dan kebudayaan.

c. Mengenal prinsip-prinsip psikologi pendidikan yang dapat dimanfaatkan dalam proses balajar mengajar

1. Mengkaji jenis perbuatan untuk memperoleh pengetahuan, keterampilan dan sikap.

2. Mengkaji prinsip- prinsip belajar

3. Menerapkan prinsip- prinsip belajar dalam kegiatan belajar mengajar.

2. Menguasai bahan pelajaran

\footnotetext{
${ }^{6}$ Hamalik, Omar, Pendidikan Guru Berdasarkan Pendekatan Kompetensi, (Jakarta; PT. Bumi Aksara.2002), 37-38
}

Falasifa, Vol. 11 Nomor 2 September 2020 | 97 
a. Menguasai bahan pengajaran kurikulum pendidikan dasar dan menengah

1. Mengkaji kurikulum pendidikan dasar dan menengah

2. Menelaah buku teks pendidikan dasar dan menengah

3. Menelaah buku pedoman khusus bidang studi.

4. Melaksanakan kegiatan- kegiatan yang dinyatakan dalam buku teks dan buku pedoman khusus.

b. Mengusai bahan pengayaan / penunjang bidang studi

1. Mengkaji bahan penunjang yang relevan dengan bahan bidang studi/ mata pelajaran

2. Mengkaji bahan penunjang yang relevan dengan profesi guru.

3. Mengelola program belajar mengajar

a. Merumuskan tujuan intruksional

b.Mengenal dan dapan menggunakan prosedur intruksional yang tepat

c. Melaksanakan program belajar mengajar

d.Mengenal kemampuan anak didik

4. Melaksanakan program pengajaran

a. Mengatur tata ruang kelas untuk pelajaran

1. Mengkaji berbagai tata ruang belajar.

2. Mengkaji kegunaan sarana dan prasarana kelas.

3. Mengatur ruang belajar yang tepat.

b. Mencipkan iklim belajar mengajar yang tepat dan serasi

1. Mengkaji prinsip- prinsip pengelolaan kelas

2. Mengkaji faktor- faktor yang mempengeruhi suasana belajar mengajar.

3. Menciptakan suasana belajar yang baik.

4. Menangani masalah pengajaran dan pengelolaan.

c. Mengelola interaksi belajar mengajar

1. Mengkaji cara- cara mengamati kegiatan belajar mengajar.

2. Dapat mengamati kegiatan belajar mengajar.

3. Menguasai berbagai keterampilan dasar mengajar.

4. Dapat menggunakan berbagai keterampilan dasar mengajar.

5. Dapat mengatur murid dalam kegiatan belajar mengajar

98 | Falasifa, Vol. 11 Nomor 2 September 2020 
5. Menguasai media atau sumber belajar
a. Mengenal, memilih dan menggunakan media.
b. Membuat alat bantu pelajaran yang sederhana
c. Menggunakan perpustakaan dalam proses belajar mengajar
d. Menggunakan micro teaching untuk unit program pengenalan lapangan. ${ }^{7}$

6. Menguasai Metode/strategi Pembelajaran

Metode mengajar adalah alat dan merupakan bagian dari perangkat alat dan cara dalam pelaksanaan suatu strategi belajar mengajar. Dan karena strategi belajar mengajar merupakan sarana atau alat untuk mencapai tujuan belajar ,maka metode mengajar juga merupakan alat pula untuk mencapai tujuan belajar. ${ }^{8}$

Beberapa metode mengajar yang digunakan oleh guru dalam proses Belajarmengajar antara lain:

a. Metode Ceramah

Metode ceramah adalah cara penyampaian bahan pelajaran dengan komunikasi lisan .Metode ceramah ekonomis dan efektif untuk keperluan penyampaian informasi dan pengertian. Teknik mengajar melalui metode ceramah ini dahulu sampai sekarang masih berjalan dan masih banyak dilakukan, namun usaha- usaha peningkatan teknik mengajar tersebut tetap berjalan terus dan para ahli menemukan beberapa kelemahannya yaitu:

1) Dalam pengajaran yang dilakukan dengan metode ceramah, perhatian hanya terpusat kepada guru dan guru dianggap murid selalu benar. Disini tampak bahwa guru lebih aktif sedangkan murid pasif saja.

2) Metode ceramah ada unsur paksaan, karena guru berbicara (aktif) sedang murid hanya mendengar, melihat dan mengutip apa yang dibicarakan guru. Murid diharuskan mengikuti apa kemauan guru, meskipun ada murid yang kritis, namun semua jalan pikiran guru dianggap benar oleh murid.

Kekurangan-kekurangan dari metode ceramah, menurut teori dapat diatasi atau dikurangi dengan menggunakan metode lain yaitu tanya jawab, atau memakai alat-

\footnotetext{
${ }^{7}$ Suryosubroto, Proses Belajar mengajar di Sekolah, (Jakarta: PT. Reneka Cipta, 1997), 5

${ }^{8}$ Hasibuan, JJ, Proses Belajar Mengajar, (Bandung, PT. Remaja Rosda Karya, 2004), 3
} Falasifa, Vol. 11 Nomor 2 September 2020 | 99 


\section{Mohammad Zaini}

alat peraga dan lain-lain. ${ }^{9}$

b. Metode Diskusi

Metode diskusi ialah proses penglihatan dua atau lebih individu yang berinteraksi secara verbal dan saling berhadapan muka mengenai tujuan atau sasaran yang sudah tertentu melalui cara tukar menukar informasi ,mempertahankan pendapat atau pemecahan masalah.

Metode diskusi ini biasanya erat kaitannya dengan metode lainnya, misalnya metode ceramah ,karyawisata dan lain-lain karena metode diskusi ini adalah bagian terpenting dalam memecahkan suatu masalah. Dalam dunia pendidikan metode diskusi ini mendapat perhatian karena dengan diskusi akan merangsang muridmurid berpikir atau mengeluarkan pendapat sendiri. Metode diskusi bukanlah hanya percakapan atau debat biasa saja, tapi diskusi timbul karena ada masalah yang memerlukan jawaban atau pendapat yang bermacam- macam. Dalam metode diskusi ini peranan guru sangat penting dalam rangka menghidupkan kegairahan murid dalam berdiskusi. Jelas diperlukan diantanya ialah:

1) Guru atau pemimpin diskusi harus berusaha dengan semaksimal mungkin agar semua murid atau anggota diskusi turut aktif dan berperan dalam diskusi tersebut.

2) Guru atau pemimpin diskusi sebagai pengatur lalu lintas pembicaraan, harus bijaksana dalam mengarahkan diskusi, sehingga diskusi tersebut berjalan lancar dan aman.

3) Membimbing diskusi agar sampai kepada suatu kesimpulan. Guru atau pemi mpin diskusi perlu ada keterampilan mengumpulkan hasil-hasil pembicaraan.

Pemimpin diskusi yang baik akan dapat menjaga kemungkinan- kemungkinan yang akan terjadi, dan sudah dipersiapakan tindakan untuk mengatasi hal- hal negatif yang mungkin timbul dalam diskusi. Fungsi diskusi antara lain:

1) Untuk merangsang murid- murid berpikir dan mengeluarkan pendapatnya sendiri, serta ikut menyumbangkan pikiran- pikiran dalam masalah bersama.

${ }^{9}$ Zakiyah Drajat, Metodik Khusus Pengajaran Agama Islam, (Jakarta, Bumi Aksara,2004), 289

100 | Falasifa, Vol. 11 Nomor 2 September 2020 
2) Untuk mengambil satu jawaban aktual atau satu rangkaian jawaban yang didasarkan atas pertimbangan yang seksama.

Untuk mengembangakan pikiran- pikiran dalam masalah bersama dan kesanggupan untuk mendapatkan jawaban atau rangkaian jawaban yang didasarkan atas pertimbangan yang seksama maka diskusi itu hendaklah dilaksanakan dengan baik dan objektif.

Macam- macam diskusi:

a. Diskusi informal

Diskusi ini terdiri dari satu diskisi yang pesertanya terdiri dari murid- murid yang jumlahnya sedikit. Peraturan peraturannya agak longgar. Dalam diskusi informal ini hanya seorang yang menjadi pimpinan, tidak perlu ada pembantupembantu, sedangkan yang lain- lainnya hanya sebagai anggota diskusi.

b. Diskusi formal

Diskusi ini berlangsung dalam suatu diskusi yang serba diatur dari pimpinan sampai dengan anggota kelompok. Kebaikan metode diskusi ini diantaranya adalah:

1) Adanya partisipasi murid yang terarah terhadap pelajaran tersebut.

2) Murid harus berpikir srcara kritis, tidak sembarang bicara

3) Murid dapat meninggalkan keberanian.

Kelemahannya antara lain:

1) Banyak waktu yang terbuang

2) Duskusi kebanyakan berlangsung diantara murid yang pandai pandai saja. ${ }^{10}$

c. Metode Tanya Jawab

Dalam proses belajar - mengajar bertanya memegang peranan yang penting, sebab pertanyan yang tersusun baik dengan teknik pengajuan yang tepat akan :

1) Meningkatkan partisipasi siswa dalam kegiatan belajar-mengajar.

2) Membangkitkan minat dan rasa ingin tahu siswa terhadap masalah yang sedang dibicarakan.

3) Mengembangkan pola berfikir dan belajar aktif siswa.

${ }^{10}$ Zakiyah Drajat, Metodik khusus Pengajaran Agama Islam, (Jakarta, Bumi Aksara,2004), 293-294

Falasifa, Vol. 11 Nomor 2 September 2020 | 101 
4) Menuntun proses berfikir siswa.

5) Memusatkan perhatian murid terhadap masalah yang sedang dibahas.

Metode tanya jawab adalah salah satu teknik mengajar yang dapat membantu kekurangan- kekurangan yang terdapat pada metode ceramah. Ini disebabkan karena guru dapat memperoleh gambaran sejauh mana murid dapat mengerti dan dapat mengungkapkan apa yang telah diceramahkan.

7. Memilki kepribadian yang ideal

Setiap guru mempunyai pribadi masing-masing, sesuai ciri-ciri pribadi yang mereka miliki. Ciri-ciri inilah yang membedakan seorang guru lain dari guru yang lainnya. Kepribadian sebenarnya adalah sesuatu masalah yang abstrak, hanya dapat dilihat lewat penampilan, tindakan, ucapan, cara berpakaian, dan dalam menghadapi setiap persoalan.

Kepribadian adalah unsur yang menentukan keakraban hubungan guru dengan anak didiknya. Kepribadian guru akan tercermin dalam sikap dan perbuatannya dalam membina dan membimbing anak didik. Profil guru yang ideal adalah sosok yang mengabdikan diri berdasarkan panggilan jiwa, panggilan hati nurani, bukan hanya tuntunan uang belaka, yang membatasi tugas dan tanggung jawabnya sebatas dinding sekolah, guru yang ideal ingin selalu bersama anak didiknya di dalam dan diluar sekolah.

\section{Kompetensi Guru dalam pendidikan}

Menurut Kamus Umum Bahasa Indonesia kompetensi berarti (kewenangan) kekuasaan untuk menentukan atau memutuskan sesuatu hal. Pengertian dasar kompetensi (competency) yakni kemampuan atau kecakapan. Istilah kompetensi sebenarnya memiliki beberapa pengertian sebagaimana yang dikemukakan beberapa ahli:

1) Kompetensi merupakan gambaran hakikat kualitatif dari perilaku guru yang tampak sangat berarti

2) Kompetensi merupakan perilaku yang rasional untuk mencapai tujuan yang dipersyaratkan sesuai dengan kondisi yang diharapkan

3) Kompetensi merupakan keadaan berwewenang atau memenuhi syarat menurut ketentuan hukum

102 | Falasifa, Vol. 11 Nomor 2 September 2020 
Reinforcement Kompetensi Guru Dalam Meningkatkan

4) Kompetensi guru merupakan kemampuan seorang guru dalam melaksanakan kewajiban-kewajiban secara bertanggung jawab dan layak. ${ }^{11}$

Dari gambaran di atas, ringkasnya pengaruh kompetensi guru merupakan daya yang ada pada kemampuan dan kewenangan pendidik dalam melaksanakan profesi keguruannya.

\section{Jenis-jenis Kompetensi Guru dalam pendidikan}

Menurut Departemen Pendidikan Dan Kebudayaan sebagaimana dikutip Sukmadinata $^{12}$, telah memformulasikan beberapa kompetensi yang harus dimiliki guru dan mengklasifikasikannya atas tiga aspek umum kompetensi yaitu, kompetensi profesional, kompetensi personal dan kompetensi sosial.

\section{Kompetensi Profesional}

Menurut Sudjana sebagaimana dikutip Usman ${ }^{13}$, kata profesional berasal dari kata sifat yang berarti mata pencahariaan dan sebagai kata benda yang berarti orang yang mempunyai keahlian seperti guru, dokter dan sebagainya". Kompetensi profesional yakni menyangkut kemampuan dan kesediaan serta tekad guru untuk mewujudkan tujuan-tujuan pendidikan yang telah dirancang melalui proses dan produk kerja yang bermutu. ${ }^{14}$

Menurut Tamyong sebagaimana dikutip Usman, mengatakan bahwa: Guru profesional adalah orang yang terdidik dan terlatih dengan baik, serta memiliki pengalaman yang kaya di bidangnya yang dimaksud dengan terdidik dan terlatih bukan hanya memperoleh pendidikan formaltetapi juga harus menguasai berbagai strategi di dalam kegiatan belajar mengajar serta menguasai landasan-landasan kependidikan.

Dengan bertitik tolak pada pengertian di atas, guru profesional adalah orang yang memiliki kemampuan dan keahlian khusus dalam bidang keguruan sehingga ia mampu melakukan tugas dan fungsinya sebagai guru dengan kemampuan maksimal.

a) Penguasaan materi pelajaran

Penguasaan bahan bagi guru adalah sangat penting dan tidak bisa ditawar- tawar lagi. Untuk dapat menguasai bahan dengan baik, maka guru harus memiliki

\footnotetext{
${ }^{11}$ Usman, Uzer, Menjadi Guru Profesional, (Bandung: Remaja Rosdakarya, 2002), 14

${ }^{12}$ Sukmadinata, Nana Syaodih, Pengembangan Kurikulum Teori Dan Praktik, Bandung: Remaja Rosdakarya, 2001)

${ }^{13}$ Usman, Uzer, 2002, Menjadi Guru Profesional, (Bandung: Remaja Rosdakarya, 2002), 14

${ }^{14}$ Muhaimin, 2002, Paradigma Pendidikan Islam, (Bandung: Remaja Rosdakarya, 2002), 115
}

Falasifa, Vol. 11 Nomor 2 September 2020 | 103 
kebiasaan untuk mencari dan menelusuri secara mandiri. Berbagai sumber pustaka dan sumber lain secara maksimal. Penguasaan bahan pada akhirnya harus ditunjukkan dengan hasil pemahaman yang memadai dengan pemberian standart penilaian yang ketat dan bermutu. ${ }^{15}$

Guru dipandang sebagai orang yang paling mengetahui, karena guru adalah yang paling pandai. Dia yang menyiapkan tugas-tugas, memberikan latihan-latihan dan penilaian. Penyusunan materi merupakan syarat yang penting, sebab guru berkewajiban menyampaikan pengetahuan, pengertian, keterampilan kepada siswa-siswanya. ${ }^{16}$ Guru harus selalu menambah pengetahuannya. Mengajar tidak dapat dipisahkan dari belajar. Guru yang pekerjaannya memberikan pengetahuanpengetahuan dan kecakapan-kecakapan kepada para siswanya, tidak mungkin akan berhasil jika guru itu sendiri tidak selalu berusaha menambah pengetahuannya. Jadi sambil mengajar, sebenarnya guru juga belajar. ${ }^{17}$ Setiap guru wajib meningkatkan ilmunya karena ilmu pengetahuan itu seperti makanan yang selalu penting bagi kehidupan manusia. Sungguh terasa janggal kalau seorang guru tidak memiliki ilmu yang luas. Bagaimana guru mengajar dan menjawab persoalan yang sedang dan dilalui kalau guru tidak mempunyai keluasaan ilmu yang memadai. Guru harus memiliki ilmu pengetahuan dalam bidang yang diajarkannnya. Sehingga memungkinkan dia untuk mentransfer ilmu pada siswanya dengan cukup baik, sesuai dengan tingkat kepada siapa ilmu itu diberikan. seorang guru yang bermental ilmu, mencintai ilmu serta senantiasa giat untuk menambah ilmunya, terutama di dalam bidang mata pelajaran yang diasuhnya.

b) Penguasaan landasan dan wawasan kependidikan dan keguruan

Guru sebagai salah satu unsur manusiawi dalam kegiatan pendidikan harus memahami hal-hal yang berkaitan dengan pendidikan nasional baik arah atau tujuan dan kebijaksanaan-kebijaksanaan pelaksanaanya. Dengan memahami hal tersebut guru akan memiliki landasan berpijak dan keyakinan yang mendorong cara berpikir dan bertindak edukatif di setiap situasi dalam usaha mengelola interaksi belajar

\footnotetext{
${ }^{15}$ Suparno, Paul dkk, Reformasi Pendidikan, (Yogyakarta Kanisius, 2002), 102

${ }^{16}$ Hamalik, Oemar, Proses Belajar Mengajar, (Jakarta: Bumi Aksara, 2003), 119

${ }^{17}$ Purwanto, Ngalim, Ilmu Pendidikan Teori dan Praktis, (Bandung: PT. Remaja Rosdakarya, 1995), 147 104 | Falasifa, Vol. 11 Nomor 2 September 2020
} 
mengajar. Dengan kata lain pancasila, UUD 1945, Sisdiknas akan merupakan landasan atau falsafah bagi kegiatan guru dalam menjalankan berbagai ketetapan pemerintah dalam bidang pendidikan ${ }^{18}$

Guru yang efektif perlu memahami pertumbuhan dan perkembangan secara komprehensif. Pemahaman ini akan memudahkan guru untuk menilai kebutuhan siswa dan merencanakan tujuan, bahan, prosedur belajar mengajar dengan tepat. ${ }^{19}$ Seorang guru harus memiliki ilmu terapan yang akan dipergunakan dalam rangka mengkomunikasikan ilmu tersebut pada siswanya. Ilmu terapan tersebut berupa, keterampilan menejemen pendidikan, tujuan pendidikan, dan kepemimpinan. Guru seharusnya memiliki kesadaran bahwasannya proses pembelajaran bisa disebut interaksi edukatif yang sadar akan tujuan pendidikan. Artinya interaksi yang telah dicanangkan untuk suatu tujuan tertentu, setidaknya adalah tercapainya tujuan instruksional yang dirumuskan dalam suatu pelajaran. Proses pembentukan setiap rencana latihan maupun pembelajaran yang baik mulai dengan penentuan tujuan pelajaran yang pokok yang harus dicakup untuk mencapai tujuan ini. ${ }^{20}$ Guru seharusnya mengkomunikasikan pada siswanya mengenai pelaksanaan belajarnya, mengemukakan standart kompetensi, kompetensi dasar dan menentukan alokasi waktu maupun kondisi belajar yang tepat bagi siswa.

c) Penguasaan proses kependidikan

Guru bertugas memberikan pengajaran di dalam sekolah. Dia menyampaikan pelajaran agar siswa memahami dengan baik, semua pengatahuan yang telah disampaikan itu. Selain dari itu ia juga berusaha agar terjadi perubahan sikap, keterampilan, kebiasaan, hubungan sosial melalui pengajaran yang diberikannya. Untuk mencapai tujuan-tujuan itu maka di samping guru perlu memahami sedalamdalamnya materi pelajaran, maka ia dituntut dapat menguasai dengan baik metode dan strategi mengajar. ${ }^{21}$

Penguasaan guru atas berbagai metode dan pendekatan belajar menjadi bagian penting berikutnya, khususnya metode dan pendekatan belajar yang menekankan

\footnotetext{
${ }^{18}$ Sardiman, Interaksi dan Motivasi, (Jakarta: Raja Grafindo Persada, 2003), 172

${ }^{19}$ Hamalik, Oemar, Proses Belajar Mengajar, (Jakarta: Bumi Aksara, 2003), 93

${ }^{20}$ Sagala, Saiful, Konsep Dan Makna Pembelajaran, (Bandung: Alfabeta,2003), 136

${ }^{21}$ Hamalik, Oemar, Proses Belajar Mengajar, (Jakarta: Bumi Aksara, 2003), 93
} 
siswa aktif. Guru diharuskan memiliki kemampuan mengkomuni-kasikan ilmunya, termasuk didalamnya adalah kemampuan persiapan mengajar, mengelola interaksi belajar mengajar yang tepat untuk mata pelajaran tertentu.

\section{Kompetensi Personal}

Kompetensi personal adalah kemampuan kepribadian yang mantap, stabil, dewasa, arif dan berwibawa menjadi teladan bagi peserta didik dan berakhlak mulia. ${ }^{22}$ Prasyarat dimensi personal ini meliputi hal-hal berikut:

a) Mengembangkan kepribadian

Dengan bertakwa kepada Tuhan Yang Maha Esa, berperan dalam masyarakat sebagai warga negara yang berjiwa pancasila. Dan mengembangkan sifat-sifat terpuji seperti ikhlas, sabar, adil yang dipersyaratkan bagi jabatan guru.

Sebagai pribadi seorang guru harus memiliki sifat-sifat yang disenangi oleh siswanya, oleh orang tua dan masyarakat. Sifat-sifat itu sangat diperlukan agar ia dapat melaksanakan pengajaran secara efektif. Tegasnya guru harus memiliki sifatsifat pribadi, baik untuk kepentingan jabatannya maupun untuk kepentingan dirinya sendiri sebagai warga Negara. ${ }^{23}$

Menurut Muhajir sebagaimana dikutip Daulay," seorang pendidik adalah seorang yang mempunyai pengetahuan lebih serta mampu menyelipkan nilai-nilai di dalamnya. Jadi guru diberi bekal pengetahuan sesuai dengan tugasnya dan pengetahuan itu mempribadi dan nilai-nilai itu mendarah daging pada guru tersebut.

Mengembangkan kepribadian dapat dimanifestasikan dalam bentuk:

1) Bertakwa pada TuhanYang Maha Esa dengan megkaji ajaran-ajaran agama yang dianut dan mengamalkan ajaran agama.

2) Berperan dalam masyarakat sebagai warga negara yang berjiwa pancasila dengan mengkaji berbagai ciri manusia pancasila dan membiasakan diri menerapkan nilai-nilai pancasila dalam kehidupan.

3) Mengembangkan sifat-sifat terpuji yang dipersyaratkan bagi jabatan guru dengan mengkaji sifat-sifat terpuji yang harus dimiliki oleh guru, membiasakan

${ }^{22}$ Soebahar, Halim, Matrik Pendidikan Islam, (Yogyakarta: Pustaka Marwa, 2005), 66

${ }^{23}$ Hamalik, Oemar, Proses Belajar Mengajar, (Jakarta: Bumi Aksara,2003), 25

106 | Falasifa, Vol. 11 Nomor 2 September 2020 
Reinforcement Kompetensi Guru Dalam Meningkatkan

diri menerapkan sifat sabar, demokratis, menghargai pendapat orang lain dan sopan santun. ${ }^{24}$

Seorang guru bukan hanya orang yang hanya bertugas mentransfer ilmu, tetapi juga orang yang bertugas mentransfer nilai. Guru tidak hanya mengisi otak siswanya, tetapi juga bertugas untuk mengisi afektifnya dengan baik. Di sini seorang guru menjadi panutan bagi siswanya dalam banyak segi dapat dijadikan contoh teladan oleh siswanya.

Seorang guru seharusnya juga memiliki komitmen moral yang tangguh, konsisten dan konsekuen menjalankan etika profesinya sebagai pendidik.

b) Berinteraksi dan berkomunikasi

Pada dasarnya pendidikan adalah proses komunikasi. Guru tidak hanya dituntut untuk mampu berinteraksi komunikasi dengan siswa, namun juga berinteraksi dengan masyarakat demi penunaian misi pendidikan. Bangunan interaksi guru dan siswa harus terjalin dengan baik. Karena hal tersebut dapat lebih memudahkan anak lebih memahami materi yang dipelajarinya. Kemampuan komunikasi dengan orang lain merupakan dasar untuk segala yang kita kerjakan. Komunikasi yang efektif, jelas, tepat dan tidak samar-samar menggunakan keterampilan-keterampilan yang diperlukan dalam komunikasi. Hal ini didasarkan pada kenyataan bahwa semua orang mempunyai kebutuhan untuk mengemukakan ide, peraaan, dan kebutuhan lain, terutama seorang guru sebagai pengajar dan pendidik. ${ }^{25}$

Menurut Medley sebagaimana dikutip Daulay, "di antara yang melandasi keberhasilan guru dan pendidikan guru adalah mengutamakan iklim interaksi di kelas. Interaksi guru di kelaslah yang paling dominan di dalam keberhasilan pendidikan. Interaksi dan komunikasi antara guru dan siswanya memberikan pengaruh yang besar terhadap berhasil tidaknya pembelajaran dan pendidikan. Kehidupan pribadi siswa sering kali diwarnai oleh situasi dan kondisi interaksinya dengan guru dan teman-temannya. Interaksi itu termasuk ketika siswa bertanya dan pada saat berdiskusi berbagai pengalaman dan perasaan. Kewajiban guru tidak hanya berinteraksi dan berkomunikasi di lingkungan sekolah saja, tetapi juga dalam

${ }^{24}$ Usman, Uzer, Menjadi Guru Profesional, (Bandung: Remaja Rosdakarya, 2003),16

${ }^{25}$ Dimyati dan Mujdiono, Belajar dan Pembelajaran, (Jakarta: Rineka Cipta, 2002),143

Falasifa, Vol. 11 Nomor 2 September 2020 | 107 
lingkungan masyarakat. Seorang guru yang merasa cukup dengan interaksi dan komunikasi dengan lingkungan sekolah saja, tentu akan kurang luas pandangannya. Implikasinya sekolah akan menjadi asing bagi bagi masyarakat jika guru-gurunya memencilkan diri. Apalagi guru sama sekali tidak pernah memasuki perkumpulanperkumpulan atau turut membantu kegiatan masyarakat sebagai bentuk kerja sama dalam peningkatan mutu pendidikan. ${ }^{26}$ Dalam pembelajaran di sekolah komunikasi guru dan siswa sangat urgen, karena merupakan kegiatan praktis dan terikat dalam suatu situasi pengaruh mempengaruhi serta terarah untuk suatu tujuan tertentu.

\section{Kompetensi Sosial}

Kompetensi sosial adalah kemampuan pendidik sebagai bagian dari masyarakat untuk berkomunikasi dan bergaul secara efektif dengan peserta didik, sesama pendidik, tenaga kependidikan dan orang tua peserta didik. ${ }^{27}$ Menurut Departemen Pendidikan dan Kebudayaan sebagaimana dikutip Sukmadinata kompetensi sosial adalah kemampuan menyesuaikan diri dengan tuntutan kerja dan lingkungan sekolah.

Perbuatan mendidik harus dilandasi oleh sikap dan keyakinan sebagai pengabdian pada nusa, bangsa dan kemanusiaan, untuk mencerdaskan bangsa dan melahirkan generasi pembangunan yang lebih handal. Kalau perbuatan mendidik hanya didorong oleh kebutuhan memperoleh nafkah, maka guru-guru hanya akan bekerja secara mekanistik dan formalitas. Idealisme dalam perbuatan mendidik akan menumbuhkan rasa cinta pada guru terhadap pekerjaan pendidikan dan siswanya. Dengan dasar rasa cinta guru akan berbuat yang terbaik bagi peserta didik dan bagi pendidikan. Idealisme dan rasa cinta mendasari dan menjiwai semua perilaku dalam mendidik. Tanpa idealisme (citacita luhur yang ingin dicapai dengan pendidikan) dan rasa cinta, kompetensi yang dimiliki oleh guru hanya akan tampak seperti lampu kekurangan minyak. ${ }^{28}$

Guru harus mengenal keadaan siswanya, agar ia dapat menyusun materi yang akan disusun oleh siswanya. Di samping guru juga selalu mengadakan inventarisasi semua masalah ynag timbul dalam kelas, kemudian dicari solusi pemecahannya.

Guru memerlukan pengetahuan dalam bidang pendidikan dan spesialisasi, namun

${ }^{26}$ Purwanto, Ngalim, Ilmu Pendidikan Teori dan Praktis, (Bandung: PT. Remaja Rosdakarya, 1995). 146-147

27 Soebahar, Halim, Matrik Pendidikan Islam, (Yogyakarta: Pustaka Marwa, 2005), 67

${ }^{28}$ Sukmadinata, Nana Syaodih, Pengembangan Kurikulum Teori dan Praktik, (Bandung: Remaja Rosdakarya, 2001), 193-194

108 | Falasifa, Vol. 11 Nomor 2 September 2020 
Reinforcement Kompetensi Guru Dalam Meningkatkan

diperlukan juga ketrampilan terintegrasi dengan masyarakat dan bekerja sama dengan baik. Seharusnya mampu membekali kemampuan dan cara menghadapi masalah yang ada dalam proses belajar mengajar, melalui luasnya wawasan, kematangan kreativitas, rasionalitas, keterlatihan memecahkan masalah. ${ }^{29}$

\section{Kompetensi Guru Terhadap Minat Belajar Siswa}

Beberapa kompetensi yang harus dimiliki guru yang mencakup kompetensi profesional, personal dan sosial, diharapkan dapat dijadikan bekal dalam meningkatkan mutu pendidikan. Dalam proses belajar mengajar terjadi antara guru dan siswa. Proses tersebut juga dipengaruhi oleh relasi yang ada dalam proses itu sendiri. Jadi cara belajar siswa juga dipengaruhi oleh relasinya dengan gurunya. Dalam relasi yang baik siswa akan menyukai gurunya dan juga akan menyukai bahan pelajaran yang diberikan. Sehingga siswa berusaha mempelajarinya dengan sebaik-baiknya. Hal tersebut juga terjadi sebaliknya, jika siswa membenci gurunya, ia segan mempelajari mata pelajaran yang diberikannya.

Guru yang kurang berinteraksi dengan siswanya, secara akrab menyebabkan proses belajar mengajar kurang lancar. Juga siswa merasa jauh dari guru, maka siswa enggan berpartisipasi secara aktif dalam belajar. ${ }^{30}$ Tujuan utama guru dalam mengajar ialah mempengaruhi perubahan tingkah laku para siswanya. Perubahan ini terjadi karena guru memberikan perlakuan-perlakuan. Tujuan lainnya adalah mendorong dan meningkatkan kemampuan sebagai hasil belajar, dengan cara itu guru dapat mempengaruhi perubahan tingkah laku siswa. Dalam pencapaian tujuan tersebut diperlukan hubungan timbal balik antara guru dan siswa. Dengan beberapa kompetensi yang dimiliki oleh guru akan berpengaruh terhadap minat belajar siswa. Siswa akan lebih menyukai untuk mempelajari bahan materi yang diajarkan guru.

Dalam metode mengajar guru harus membuang paksaan terhadap siswa, guru harus membangkitkan implus anak didik sehingga timbul kekuatan internal untuk mencapai mastery (ketuntasan). Agar dapat muncul minat, guru harus intim dengan kecakapan dan minat siswa. ${ }^{31}$ Kesempatan belajar yang diciptakan guru adalah agar merangsang siswa untuk belajar, berpikir melakukan penalaran. Jadi memungkinkan siswa untuk belajar sendiri. Guru harus memahami

\footnotetext{
${ }^{29}$ Djohar, Pendidikan Strategik, (Yogyakarta: LESFI, 2003), 113

${ }^{30}$ Slameto, Belajar dan Faktor-faktor yang Memperngaruhinya, (Jakarta: Rineka Cipta, 2003), 66

${ }^{31}$ Sad Iman, Muis, Pendidikan Partisipatif, (Yogyakarta: Safiria Insania Pers, 2004), 81
}

Falasifa, Vol. 11 Nomor 2 September 2020 | 109 


\section{Mohammad Zaini}

tahap pembangunan siswa, kemampuan-kemampuan, kekurangan dan kelebihannya. Sehingga guru mampu memprediksi strategi yang akan diterapkan agar siswa menikmati proses belajar mengajar tersebut.

Guru di sekolah berfungsi sebagai penunjuk jalan sekaligus pengamat tingkah laku anak untuk dapat mengetahui hal yang menarik minat siswa. Dan dengan pengamatannya itu guru dapat menentukan masalah yang akan dijadikan pusat minat siswa. Setiap siswa memiliki minat dan kebutuhan sendiri-sendiri. Dalam hal pembelajaran, bahan ajaran dan penyampaian sedapat mungkin disesuaikan dengan minat dan kebutuhan tersebut. Walaupun sangat sulit untuk menyesuaikan pengajaran dengan minat dan kebutuhan setiap siswa, namun sedapat mungkin perbedaan-perbedaan minat tersebut dapat dipenuhi.

Dengan beberapa kompetensi yang dimiliki guru, maka dalam pembelajaran guru akan memperhatikan minat dan kebutuhan, sebab keduanya akan menjadi penyebab timbulnya perhatian. Sesuatu yang menarik minat dan dibutuhkan siswa, tentu akan menarik perhatiannya, dengan demikian mereka akan bersungguh-sungguh dalam belajar. ${ }^{32}$ Pengajaran harus disesuaikan dengan minat-minat, sebab apabila tidak, maka pengajaran itu tidak akan banyak hasilnya. Menurut Tirtoraharjda dan Sula sebagaimana dikutip Sagala, "minat terhadap masyarakat adalah dorongan sibuk bermain-main dan dorongan imitasi yang digunakan sebagai pusat-pusat minat". Sedangkan pengajaran dan pendidikan harus selalu dihubungkan dengan pusat-pusat minat tersebut. Gerakan pengajaran pusat tersebut telah mendorong berbagai upaya agar dalam kegiatan belajar mengajar diadakan berbagai variasi cara mengajar agar perhatian para siswa tetap terpusat pada bahan ajaran. Peluang untuk memvariasikan pengajaran terbuka luas dengan kemajuan teknologi, hal ini menyebabkan upaya menarik minat belajar menjadi lebih besar. Belajar dengan minat akan mendorong siswa belajar dengan baik daripada belajar tanpa minat. Minat ini timbul apabila siswa tertarik akan sesuatu karena sesuai dengan kebutuhannya atau merasa bahwa sesuatu yang akan dipelajari dirasakan bermakna bagi dirinya. Jadi kompetensi yang dimiliki guru akan berpengaruh terhadap minat belajar siswa dan hasilnya akan memperkaya kegiatan belajar mengajar pada kelas yang bersangkutan.

Perihal mengenai teori tentang guru professional telah banyak dikemukakan oleh para pakar menejmen pendidikan, seperti Rice dan Bishoprick, dan Gickman Menurut Rice dan Bishoprick guru professional adalah guru yang mampu mengelola dirinya sendiridalam

\footnotetext{
${ }^{32}$ Sagala, Saiful, Konsep Dan Makna Pembelajaran, (Bandung: Alfabeta, 2003),152 110 | Falasifa, Vol. 11 Nomor 2 September 2020
} 
Reinforcement Kompetensi Guru Dalam Meningkatkean

melaksanakan tugas-tugasnya sehari-hari. Profesionalisasi guru olehkedua pakar tesebut dipandang sebagai suatu proses yang bergerak dariketidaktahuan (ignorance) menjadi tahu, dari ketidak matangan (immaturity) menjadi matang, dari diarahkan oleh orang lain (otherdirectedness) menjadi mengarahkan diri sendiri ${ }^{33}$

UU Nomor 14 tahun 2005 tentang Guru dan Dosen dan PP Nomor 19/2005 telah merumuskan parameter bagaimana seorang guru bisa dikategorikan sebagai pendidik yang professional. Merujuk pada UU dan PP tersebut, seorang pendidik dikatakan memiliki keprofesionalan jika mereka setidaknya memiliki 4 kompetensi. yaitu: (1) kompetensi pedagogik, (2) kompetensi Kepribadian, (3) kompetensi profesional dan ke (4) kompetensi sosial. Namun demikian untuk menjadi pendidik yang profesioanl diperlukan usaha-usaha yang sistemik dan konsisten serta berkesinambungan dari pendidik itu sendiri dan para pihak pengambil kebijakan ${ }^{34}$

\section{KESIMPULAN}

Upaya merumuskan tujuan pembelajaran dapat memberikan manfaat tertentu, baik bagi guru maupun siswa ada 4 (empat) manfaat dari tujuan pembelajaran, yaitu: (1) memudahkan dalam mengkomunikasikan maksud kegiatan belajar mengajar kepada siswa, sehingga siswa dapat melakukan perbuatan belajarnya secara lebih mandiri; (2) memudahkan guru memilih dan menyusun bahan ajar; (3) membantu memudahkan guru menentukan kegiatan belajar dan media pembelajaran; (4) memudahkan guru mengadakan penilaian. Tujuan pembelajaran memberikan petunjuk untuk memilih isi mata pelajaran, menata urutan topik-topik, mengalokasikan waktu, petunjuk dalam memilih alat-alat bantu pengajaran dan prosedur pengajaran, serta menyediakan ukuran (standar) untuk mengukur prestasi belajar siswa.

Adapun tujuan pembelajaran adalah membantu siswa agar memperoleh berbagai pengalaman, sehingga tingkah laku siswa bertambah, baik kuantitas maupun kualitas. Pengalaman tersebut meliputi pengetahuan, ketrampilan dan nilai atau norma yang berfungsi sebagai pengendali sikap dan perilaku. Pembelajaran dilakukan dengan pengaturan bermacammacam interaksi yang ada di dalam dan di sekitar momen belajar yang mencakup unsur-unsur belajar efektif yang mempengaruhi kesuksesan siswa. Pembelajaran yang baik menurut aliran

\footnotetext{
${ }^{33}$ Ibrahim Bafadal, Peningkatan Profesionalisme Guru Sekolah Dasar, (Jakarta: PT Bumi Aksara, 2008)

${ }^{34}$ Pusat Kurikulum Depdiknas, Standar Kompetensi Mata Pelajaran Agama Islam Sekolah Dasar dan Madrasah Ibtidaiyyah, (Jakarta: Depdiknas. 2004)
} 


\section{Mohammad Zaini}

Gestalt, yaitu usaha untuk memberi materi pelajaran sedemikian rupa sehingga siswa lebih mudah mengorganisasikannya (mengaturnya) menjadi suatu pola bermakna.

\section{DAFTAR PUSTAKA}

Dimyati dan Mujdiono, 2002, Belajar dan Pembelajaran, Jakarta: Rineka Cipta.

Djohar, 2003, Pendidikan Strategik, Yogyakarta: LESFI.

Hamalik, Omar, 2002, Pendidikan Guru Berdasarkan Pendekatan Kompetensi, Jakarta; PT. Bumi Aksara.

, Proses Belajar Mengajar, Jakarta: Bumi Aksara.

Hasibuan, JJ, 2004, Proses Belajar Mengajar, Bandung, PT. Remaja Rosda Karya.

Muhaimin, 2002, Paradigma Pendidikan Islam, Bandung: Remaja Rosdakarya.

Ibrahim Bafadal, 2008, Peningkatan Profesionalisme Guru Sekolah Dasar, Jakarta: PT Bumi Aksara.

Pusat Kurikulum Depdiknas, 2004, Standar Kompetensi Mata Pelajaran Agama Islam Sekolah Dasar dan Madrasah Ibtidaiyyah, Jakarta: Depdiknas.

Suparno, Paul dkk, 2002, Reformasi Pendidikan, Yogyakarta Kanisius.

Purwanto, Ngalim, 1995, Ilmu Pendidikan Teori dan Praktis, Bandung: PT. Remaja Rosdakarya.

Sukmadinata, Nana Syaodih, 2001, Pengembangan Kurikulum Teori Dan Praktik, Bandung: Remaja Rosdakarya.

Usman, Uzer, 2003, Menjadi Guru Profesional, Bandung: Remaja Rosdakarya.

Soebahar, Halim, 2005, Matrik Pendidikan Islam, Yogyakarta: Pustaka Marwa.

Sukmadinata, Nana Syaodih, 2001, Pengembangan Kurikulum Teori dan Praktik, Bandung: Remaja Rosdakarya.

Slameto, 2003, Belajar dan Faktor-faktor yang Memperngarubinya, Jakarta: Rineka Cipta.

Sardiman, 2003, Interaksi dan Motivasi, Jakarta: Raja Grafindo Persada.

Sagala, Saiful, 2003, Konsep Dan Makna Pembelajaran, Bandung: Alfabeta.

Soebahar, Halim, 2005, Matrik Pendidikan Islam, Yogyakarta: Pustaka Marwa.

Suryosubroto, 1997, Proses Belajar mengajar di Sekolah, Jakarta: PT. Reneka Cipta.

Sardiman, A,M. 1990, Interaksi dan Motivasi Belajar Mengajar, Jakarta: Rajawali.

Soetjipto, 2000, Profesi Keguruan, Jakarta, Reneka Cipta.

Sad Iman, Muis, 2004, Pendidikan Partisipatif, Yogyakarta: Safiria Insania Pers.

Sagala, Saiful, 2003, Konsep Dan Makna Pembelajaran, Bandung: Alfabeta.

Undang-Undang No. 20 Tahun 2003 tentang Sistem Pendidikan Nasional, Bab I Pasal I ayat (2)

Undang-Undang no 14 tahun 2005 tentang Guru dan Dosen.

You Tung, Khoe, 2002, Simpone Sendib Pendidikan Nasional, Refleksi Dunia Pendidikan Nasional Kumpulan Artikel Tentang Ulasan Kritis Tentang Kepedihan, Kegetiran Dan Kepribatinan Atas Kritis Pendidikan Kita, Jakarta, Abadi Tandur.

Zakiyah Drajat, 2004, Metodik Khusus Pengajaran Agama Islam, Jakarta, Bumi Aksara.

112 | Falasifa, Vol. 11 Nomor 2 September 2020 